\title{
A diachronic account of converbal constructions in Old Rajasthani
}

\author{
Abstract \\ The aim of the paper is to present results of a multilayered diachronic analysis of one of the most \\ important subordinating devices in IA, i.e. converbs. This is a corpus-oriented study based on an \\ early variety of NIA, namely Old Rajasthani. We discuss: a) the morphology of the converb and \\ its possible diachronic pathways of evolution; b) the syntactic properties of converbal chains with \\ a special focus on main argument marking and the 'same-subject constraint' and c) the semantics \\ of the constructions and the adverbial and clause-chaining properties of converbs. The results of \\ our research bring interesting implications as regards the aspectual status of the converb which \\ seems to determine the main argument marking in converbal chains.
}

Key words: Early New Indo-Aryan, Old Rajasthani, converb, historical morphosyntax

\section{Introduction}

The term "converb" stems from Altaic linguistics (Ramstedt 1903), as the phenomenon occurs in many forms in Turkish, Mongolian and other related languages. Only much later the notion of “converb" was employed in typological linguistics (cf. Haspelmath \& König 1995). Since Haspelmath (1995), an attempt to outline a cross-linguistic, universal definition of "converb", this 
category has been well known in typological linguistics. In order to define the concept, Haspelmath (1995) lists a number of properties specific to converbs, the most important ones being non-finiteness, adverbial modification and subordination. In his words, "converbs are verbal adverbs, just like participles are verbal adjectives" (Haspelmath 1995: 3). However, as for all universal concepts, it is unclear how many properties of a category should be present to assume that the category is identical across more than one language. In his review of Haspelmath (1995), Bickel (1998) is not convinced of the universality of the concept of 'converb', but instead assumes that that there are at least two types of categories subsumed under Haspelmath's definition, a European and an Asian one. Moreover, he argues that to define a converb as purely "adverbial" is sensu stricto too limited; in many cases the converb functions on an "adsentential" level, "providing a topic or framework for subsequent discourse" (Bickel 1998: 384), rather than simply modifying a sentence. Furthermore, Haspelmath distinguishes different layers in the analysis of converbs, i.e. analyses of converbs can/must be performed on a syntactic, morphological and semantic level. Only by taking into consideration these three levels, we can hope to find a convincing definition of converbs.

The goal of this study is less ambitious: we aim to describe the development and the features of converbs in the earliest stages of New Indo-Aryan (NIA). In Indo-Aryan (IA) linguistics, they were studied from an Indo-European point of view, a classical approach which considers them as participial forms (hence, the traditional names such as 'gerund' (e.g. Tikkanen 1987) or ‘conjunctive participle' (e.g. Kellogg 1876: 162; Caldwell 1875: 398)). However, in later works and after noticing that a similar construction also occurs in Dravidian, a more typological perspective has been taken, as can be found in the works of Davison (1981), Kachru (1981), 
Subbarao (2012) etc. Furthermore, converbal constructions are mentioned as a defining feature of the linguistic area of South Asia (Masica 1976).

Besides describing the synchronic properties of converbs, certain diachronic questions rise about the development of converbs in languages. Haspelmath (1995: 17) mentions two possible origins of converbs. The most common origin is the verb combined with a case ending. Typical for the classical languages such as Latin and Greek, invariant forms of participles were used in a converbal sense. The second source of converbs can be co-predicative participles which in the course of time became uninflected forms. However, as Haspelmath (1995: 17) acknowledges himself, cross-linguistically the origin of converbs needs further investigation. There is a second diachronic point of interest, i.e., how does the converb further evolve? In particular, according to Haspelmath (1995: 37), converbs could easily grammaticalize into adpositions ${ }^{1}$, losing their "verbal" meaning, but gaining a meaning more related to case. The Hindi converb lekar is such an example, used in the adpositional sense of 'with' instead of the verbal 'after having taken'. Historical investigations of the development of converbs in IA languages have thus far not been undertaken in a systemic, empirical way. This study is a first attempt to give an overview of the properties of converbs in Old Rajasthani, a language belonging to the IA branch. Following Bickel, we distinguish the three different layers of syntax, semantics and morphology, to be as exhaustive as possible.

Our data is a 10000 word annotated corpus of Old Rajasthani short prose texts ranging from the $14^{\text {th }}$ to the $18^{\text {th }}$ century (Bhānāvat and Kamal 1997-1998). The corpus has been annotated by means of IATagger (Jaworski 2015) at the level of morphosyntax and semantics.

\footnotetext{
${ }^{1}$ Consider, for instance, the form $\bar{a} d \bar{a} y a$, meaning 'taking' in Sanskrit, which has grammaticalized into the postposition with the meaning 'with' in Pali (Bloch 1965:159).
} 
We will also refer occasionally to patterns found in Pahari, Awadhi and Braj, other Early NIA languages, which were spoken in the same time and environment as Old Rajasthani. For these languages, we are also developing corpora of the same size.

In the main body of the article, we will often refer to the use of converbs in modern NIA, in particular Hindi and Rajasthani. The studies available on modern NIA are considered as a point of departure for historical comparison. The article is structured as follows: in the next section, we will discuss the attested forms of the converb in Old Rajasthani, and possible diachronic pathways of evolutions that these forms have followed. Third, the syntactic constructions in which these converbs occur will be discussed, in particular with reference to the marking of the arguments they occur with, the so-called "same-subject constraint", and their use in serial verb constructions. Fourth, we discuss the semantics of the construction and the adverbial and clausechaining properties of converbs. In the last section, we conclude by giving an outline of the properties of Old Rajasthani converbal forms.

\section{Morphology of Old Rajasthani converbs}

Converbs are generally non-finite forms, which means that they are considered to be verbal, but they do not indicate any marker of tense, aspect, mood or agreement. The bare root form is the formal equivalent of such a non-finite form, since there are indeed no formal indications of any of these parameters. Among the varieties of converbal forms in modern NIA, simple roots can occur 
as converbs in Hindi. Apart from these root forms, Hindi speakers add the suffix -kar (or a contracted form -ke) in order to form a converb. This seems to go back to the Apabhramśa form kari (< Skt. krte, locative of the past perfect participle krta) derived from the verb kar- 'to do' (cf. Oberlies 2005: 44, Reinöhl 2016). In Nepali, we find a more extensive spectrum of converbal forms, for instance, the form ending on - era, arguably an old participial form (Bickel 1998), and forms ending on $-\bar{\imath}$ or in $-\bar{\imath} k a n a$ (the last one being emphatic and usually used in negation).

In our study, we looked at a sample of Old Rajasthani texts from the $14^{\text {th }}$ century onwards. We found a number of different formations of converbs, given in Table 1. 
Table 1 Morpohology of the Early Rajasthani converb

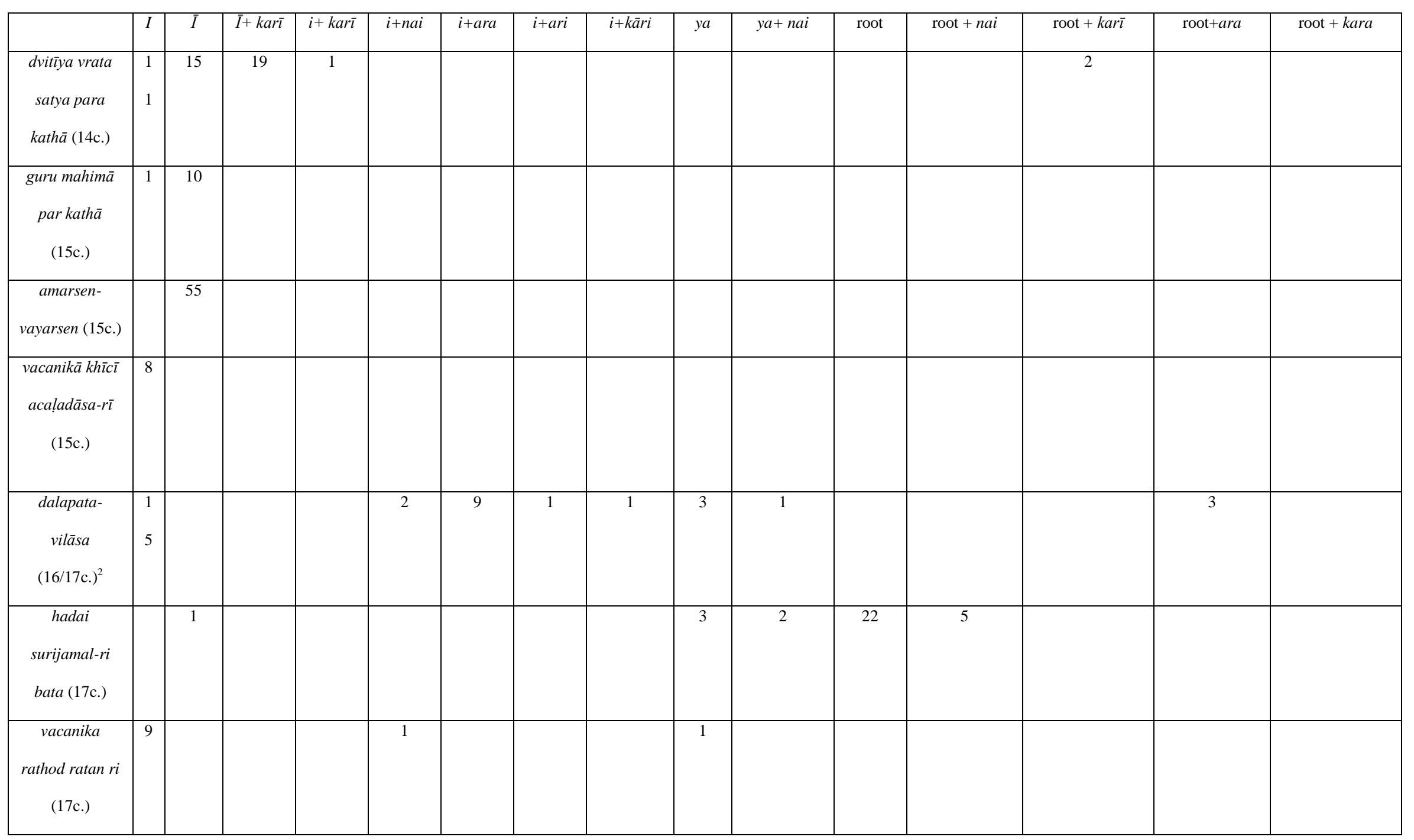

${ }^{2}$ The Dalpat Vilas was probably written during Maharaja Rai Singh's rule in the period 1579-1612 C.E. 


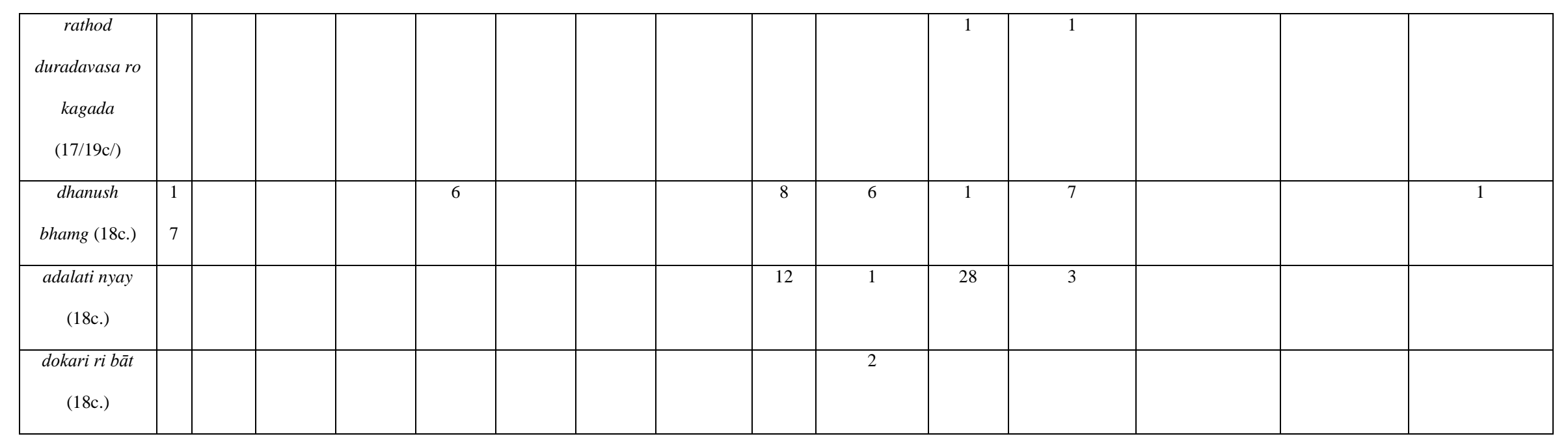


The verb followed by the suffixes $-\bar{l}$ and $-i$ is the most frequent converbal form. For instance, in the following example, the converb dekhi is used:

(1) te dekh-īsmaya hüntu loka

this see-CVB ${ }^{3} \quad$ astonished be.PTCP.PRS.M.NOM.SG people.M.NOM.SG

teha-hnaim püjābhakti karaim.

s/he-ACC worship.F.NOM.SG do.PRS.3PL

'Having seen it, the astonished people worshipped him.' $15^{\text {th }}$ c. (R.C.)

In our Old Rajasthani data, the root of the verb (cadha in the ex. (2)) was already in use in the sense of a converb:

(2) tarai rāṇo ghoṛi cạ̣ha sürajamala=nūm

then king.M.NOM.SG horse.M.OBL.SG climb.CVB Surajmal=ACC jhațako vāyo

sword.M.NOM.SG strike.PST.M.SG

'Then the king, having climbed on his horse, stroke Surajmal with his sword.' $17^{\text {th }} \mathrm{c}$ (R.C.)

The origin of the Hindi converbal suffix - kar is also clear from our data, as there are a number of instances of an $-\bar{l}$ and $-i$ form followed by karī or kari, which is, in itself, a converb of 'to do'.

\footnotetext{
${ }^{3}$ The following abbreviations occur in the glosses: ABL: ablative, ACC: accusative, AUX: auxiliary, CVB: converb, ERG: ergative, F: feminine, FUT: future, GEN: genitive, INF: infinitive, LOC: locative, M: masculine, NOM: nominative, OBL: oblique, PL: plural, PRS: present, PST: past, PTCP: participle, SBJV: subjunctive, SG: singular, TR: transitive.
} 
(3) mārgu melhī-karī äghau cāliu

way.M.NOM.SG leave-CVB far go.PST.M.SG

'Having left the road, he went further on.' $14^{\text {th }}$ c. (R.G.)

The suffix - ara is also sometimes added, the origin of it is unclear, but it is perhaps related to Modern Nepali - era.

(4) pāchai damāmo

$$
\text { de-ara caḍiyo akabara }
$$

after drum.M.NOM.SG give-CVB climb.PST.M.SG Akbar.NOM.M.SG

pātisāha dilī-nūm

king.NOM.M.SG Delhi-ACC

'After giving the order to the drums, King Akbar climbed up to Delhi.' $16 / 17^{\text {th }}$ c. (R.G.)

The form followed by a postposition nai is not common anymore in contemporary NIA. nai can be added to the root of the verb (5), but also to a form extended by a pleonastic suffix $-a$ (cf. Tessitori 1915: 105), as in ex. (6).

(5) to hūm bhāṇā sarīkhā pātra=nai de-nai then I.NOM.SG Bhana.NOM.SG like poet=ACC give-CVB amara karūm immortal.NOM.M.SG do.SBJV.1SG

'Then, after I gave them a poet as Bhana, I shall act as an immortal.' $17^{\text {th }}$ c. (R.G.)

(6) $t i \quad$ vāraipaga dhoya-nai nad̄ pāra ūtariyā this time foot.M.NOM.PL wash-CVB river.F across pass.PST.M.PL 'Then, after he washed his feet, he passed across the river.' $18^{\text {th }}$ c. (R.G.) 
It is unclear whether this latter form, exemplified by dhoyanai (from dhoya- 'wash') should be counted as a converb, or as a participial form taking case endings. Semantically though, it has clearly a different function from a participle, as it adverbially modifies the event expressed in the main verb. The formation clearly shows the non-finite nature of converbs, and their position between nominal and verbal forms. We also find forms of verbs ending on $-i$, followed by nai, e.g. dekhinai. This formation seems to be purely nominal: the regular ending of a converb in Old Rajasthani $-\bar{\imath}$ has been interpreted as a locative case ending (Tessitori 1915: 119; see also Chatterji 1926: 1010-1011) although there has also been another, even more common, hypothesis deriving the converbal ending from Apabhramśa - $i$ < Skt. -ya (e.g. Jha 1958: 514; Oberlies 2005 : 44). By adding the postposition $n a i^{4}$, which is a multifunctional postposition normally used to indicate (pro)nominal core arguments, one gets a better grip on the function of this postposition in Old Rajasthani: it functions merely as a reinforcement of the oblique (locative), indicating that an argument is no longer in the unmarked, nominative case. In these examples in particular, it indicates that the verb has assumed an adverbial function.

As expected when considering nai as a reinforcement, we notice that in texts up to the $14^{\text {th }}$ century, the form on $-\bar{l}$ and $-i$ are clearly preferred; in later texts such as the Dalpata Vilasa from the $16^{\text {th }}$ century, all forms are attested. We can assume that the addition of nai has developed in parallel with the tendency towards postpositional marking of arguments that followed the extensive case syncretism in Prakrit. When gradually the function of nai became specified towards indicating core arguments with a high level of animacy, nai as a marker of a converb disappeared, until it stopped occurring in Modern Rajasthani.

\footnotetext{
${ }^{4}$ Tessitori (1915: 119) derived nai from the locative kane which is possible interpretation of the origin of this postpostion but there are also other possible derivations and no one has been proved final (cf. Stroński 2009).
} 
Comparative data from other IA languages clearly shows that the preferred form in early NIA was the one terminating in $-i$. This is the form attested in early Awadhi e.g. $\bar{a}-i$ 'having come' (Jāyasī 'Padmāvat'1540 A.D.) along the ones terminating in: kai e.g. dekhi kai 'having seen' (Jāyas̄̄ 'Padmāvat' 1540 A.D.; cf. Śukla 1965: 153), kara e.g. jāi kara 'having gone' and kari e.g. khāi kari ‘having eaten’ (Tulsīdās ‘Rāmcāritamānas’ 1575 A.D.; cf. Saksena 1972 [1937]: 281). Early Pahari had a main converbal form terminating in $-i$ e.g. Nepali ghāl-i 'having put' (inscription from 1398 A.D.; Pokharel 1963: 32) but the form in -era appeared in Nepali also quite early - jag-era 'having saved' (inscription from 1398 A.D. (Chalise 2006: 267)).

\section{Syntactic dimensions of the converbs in Old Rajasthani, with particular emphasis on the "same-subject constraint".}

Just as for so many other linguistic topics, converbs in Hindi are the best studied in IA. One of

the main points of study is the so-called "same-subject constraint", according to which the subject of the converb must be coreferential with the subject of the main verb (see for example Subbarao 2012: 264-282). Most commonly, it follows that the main verb determines the marking of the subject, not the converb - there is no separate, explicit mention of the subject of the converb. At first sight, it turns out that this is a valuable constraint for Hindi-Urdu. However, after further investigations, it appears that pragmatic motivations can also play part (cf. Tikkanen 1995: 496), and the converbal subject is then coreferential with another (overt) argument, not necessarily the subject argument. Consider the following examples: example (7) shows a construction in which the main verb and the converb share the subject rām. Hindi has an ergative case marking pattern in perfective constructions, but in this example, there is no ergative marking of the subject 
because the main verb is intransitive - in contrast to the converb. The example (8) is the opposite situation, with a transitive main verb, which motivates the ergative marking of the subject rām. Example (9) is an unlikely construction, since the subject of the converb is not coreferential to any argument of the main verb. However, a transgression of the same-subject constraint is possible as well, as ex. (10) and (11, from Bickel and Yadav 2000: 351) show. The difference between the ungrammatical (9) and the grammatical (10) is of course that the subject of the converb in the last two constructions is involved as a salient argument in the main clause as well, though not necessarily being the subject argument. In (11), this is less clear, though it is implied that there will not be work for you. In that sense, tumhäre is an argument of the main clause as well. Note that the subject of the converb, tumhäre, is a genitive form, which indicates the tendency to nominality of the converb. An alternative translation would be "your not coming". With regard to the the genitive case of tumhäre, this is a different construction from a dative subject construction. It is unlikely that tumhare would be replaced by a dative form in this particular construction.

(7) $\mathbf{r a \overline { m }}$ soc-kar ghar calā gayā Ram.M.NOM.SG think-CVB home go.PST.M.SG go.AUX.PST.M.SG 'Ram, having thought, went home'.

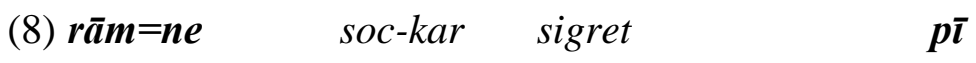

Ram.M.=ERG think-CVB cigarette.F.NOM.SG drink.PST.F.SG

'Ram, having thought, smoked a cigarette.'

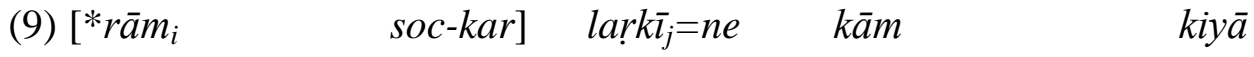




\section{Ram.M.NOM.SG think-CVB girl.F=ERG work.M.NOM.SG do.PST.M.SG \\ *'Ram having thought, the girl did the work.'}

(10) yaham nahịm ā-kar maị̣ tujhe $e_{i}$ kuch nahīm sikhā

here not come-CVB I.NOM.SG you.OBL.SG nothing teach saktā+hūm

can+be.PRS.1SG

'If you don't come here I will not be able to teach you.'

(11) tumhāre kal nahīn ā-kar kuch kām nahịm hogā

your.GEN.SG tomorrow not come-CVB some work.M.not be.FUT.M.SG

'If you don't come tomorrow, there won't be any work.'

The second language which is often cited with regard to converbs, is Nepali. Of Nepali, it is generally agreed that the subject of the converb is pragmatically determined. Consider the following example from Bickel (1998: 394):
(12) $\operatorname{tim} \bar{\imath}=l e$
bhan-era mātrai yo kām
gar-em
you=ERG say-CVB only this work.M.NOM.SG do-PST.1SG
'I did this work only because you told me so.'

This example shows the subject of the converb with an ergative marking, whereas the subject of the main clause is an unexpressed first person. In Wallace's opinion (1982), converbs in Nepali are as per definition perfective ${ }^{5}$; thus, if they are transitive, their subject is marked with the ergative case. However, in Nepali, in many cases, the subject of the converb is different from that

\footnotetext{
${ }^{5}$ Several scholars claimed the perfectivity of Hindi converb (e.g. Davison 1981: 117-121); others (Kachru 1981) added to this interpretation meanings such as simultaneity. It seems that the diachronic evidence from early NIA rather confirms the predominant perfective status of the converb (Stronski and Tokaj 2015) but certainly more research has to be done in this respect.
} 
of the main verb. Hence, there is no conjunction reduction and both subjects are marked according to the transitivity of their controlling verbs. What is remarkable though, is that when both the main verb and the converb share the same subject, its case marking is either determined by the transitivity of the main verb or by the converb. Both options are possible. Below are two of Wallace's examples (1982: 168) in which the converb is transitive and the main verb intransitive, and both times, the converb determines the ergative marking of the subject:

(13) mai=le tyas=lāi bheț-era ghar $=m \bar{a}$ ga-em

$\mathrm{I}=\mathrm{ERG}$ he=ACC meet-CVB house=in go-PST.1SG

'I met him and went home.'

(14) $u s=l e \quad$ bikh khä-era mar-yo

he=ERG poison eat-CVB die-PST.3SG

'He died while eating poison.'

Nevertheless, the opposite pattern is more frequent, when the main verb determines the case marking of the subject, as illustrated in the next example (Hutt 1997: 49).

(15) un̄ korībātī gar-era jhyāl=mā ga-era daț-in she make-up do-CVB window=in go-CVB stand-PST.F3SG 'After she put on her make-up, she went standing in the window.'

The same observations have been made for Assamese (Verbeke 2013: 116-117). Consider the following example (Baruah 1980: 865), in which the subject of the converb takes the ergative ending $-e$. 
(16) mīnuw-e chabi āṃkiba-lai kal-at si chabi āṃkiba-lai dhar-il-e

Minu-ERG picture draw-ACC ask-CVB he picture draw-ACC begin-PST-TR.3SG 'After Minu asked to draw a picture, he started to draw a picture.'

Both Assamese and Nepali show a spread of ergative marking towards imperfective constructions, which perhaps underscores their pragmatic approach towards subject marking. Note that it also seems to be a rule in Assamese that the marking of the subject is determined by the verb which is linearly the closest to the subject (Verbeke 2013: 117).

In contrast to Nepali and Assamese, Old Rajasthani generally obeys the same-subject constraint, and the marking of the shared argument is decided by the main verb. Consider the following examples. In ex. (17), hamsu is nominative because the main verb cāliu is intransitive, whereas in ex. (18), we find an oblique (ergative) form for yakși, because the verb ghätiu is transitive.

$$
\begin{aligned}
& \text { (17) isaum bhaṇīkari haṃsu rājā āghau cāliu. } \\
& \text { like talk-CVB Hansu king[M]NOM.SG far go.PST.M.SG }
\end{aligned}
$$

'Having said this king Hansu went further'.14th c. (R.G.)

(18) yakṣ-i arjuna ripu bāmmdhī-karī page

Yaksha[M]-OBL.SG Arjuna enemy[M]NOM.SG bind-CVB foot.M.LOC.PL ạni ghätiu

come.CVB throw.PST.M.SG

'Yaksha, having bound the enemy named Arjuna, threw him on his feet'. 14th c. (R.G.)

The controller of the converb, however, does not always need to be the same subject as that of the main verb. Consider, for instance, the following examples: 
(19)

ara hemu

Pānīpaṃtha $\quad \bar{a} i$

$\operatorname{der} \bar{a}$

pariy $\bar{a}$

and hemu.M.NOM.SG Panipat come.CVB camp.M.NOM.PL fall.PST.M.PL

' And after that Hemu had come to Panipat, the camps were established.' $16 / 17^{\text {th }}$ c. (R.G.)

(20) $t i$ puruṣa raja=nai vacani karī samgha=māhi these man.M.NOM.PL king=OBL speech.F.NOM.SG do.CVB community=in gay $\bar{a}$ go.PST.M.PL

'These men on hearing the king's speech (lit. of the king having spoken) went happy to their community.' $16 / 17^{\text {th }}$ (R.G.)

(21) tina sahanāna-nūm dekha mo=nūm khabara parasai that sign=OBL see.CVB I=OBL informationbe found.PRS.SBJV.3SG 'Having seen the sign, I would get the information.' $18^{\text {th }}$ (R.G.)

Examples (19) and (20) are actually a kind of an absolute construction (i.e. construction not sharing a subject argument with the main clause) which had been attested in IA throughout its history but with an inflected participle as the verbal form being in concord with a head noun.

Comparative evidence from other early NIA tongues, e.g. Awadhi (22), (24) or Pahari (Old Nepali) (23) shows that same subject constraint was not always observed in converbal chain constructions. Examples (21), (23) and (24) in particular are interesting, since they show that the subject of the converb is coreferential with the experiencer subject in a non-nominative case of the main verb (even if it is not overt as in (24)). 
Experiencer subjects occupy a special place in the discussion on subjecthood in South Asian languages. In contemporary NIA they are almost fully endowed with subject behavioural properties - e.g. they control (but do not undergo) coreferential deletion in conjunction reduction and converbal chain constructions, control reflexives etc. (for an extensive discussion see Verma and Mohanan 1991). Our data only confirms that in early NIA dative experiencers had exactly the same subject properties as in contemporary NIA.

(22) Old Awadhi (J.52.5)

sūra karasa=som birīīa

sun.M.NOM.SG touchstone=ABL become.PST.M.SG play.M.NOM.SG

kirina jāmi upan̄a naga

ray.F.NOM.SG be born.CVB origin.PST.M.SG precious stone.M.NOM.SG

hīrā

diamond.M.NOM.SG

'When the play has started from the sun's touchstone, sunrays having been born, precious stones diamonds were formed.'

(23) Old Nepali 1398 A.D. (Chalise 2007: 267)

4 kilā bhītra-ko jagā jag-era apnam gar-i

4 boundary inside-GEN cultivated land save-CVB own make.CVB

rāmadāsa pādhyā-lāhi mayā bhai-cha

Ramdas Padhya-OBL grand of land to a Brahmin gift be.PST-3SG.PRS 
'Having saved and made as its own cultivated land within four boundaries the brahmin's gift was presented to Ramdas Padhya.'

(24) Old Awadhi (J.31.8)

dekhi rūpa saravara=kara, gai piāsa see.CVB beauty lake=GEN go.PST.F.SG thirst.F.NOM.SG

au bhükha

and hunger.F.NOM.SG

'(Somebody)having seen the beauty of the lake, thirst and hunger are gone.'

Note, however, that the subject marking is sometimes obscured as in ex. (25), because the ergative case marking gradually disappears in Old Rajasthani, in favour of a nominativeaccusative argument pattern.

$\begin{array}{lccc}\text { (25) sūrajamala } & \text { doḍa-nai } & \text { pūranamala=nūm } & \text { pādiyo } \\ \text { Surajamal.NOM.SG } & \text { run-CVB } & \text { Puranmal=ACC } & \text { knock down.PST.M.SG } \\ \text { 'Surajmal having ran knocked Puranmal down.' } 17^{\text {th }} \text { c. (R.G.) } & \end{array}$

With finite constructions, we notice that at least up to the $16^{\text {th }}$ century, there is seemingly unmotivated variation between marked and unmarked forms of A. Only with the pronominal forms, A and $\mathrm{S}^{6}$ receive a different, specific marking up till the $18^{\text {th }}$ century (instrumental/oblique for A, nominative for S). In Modern Rajasthani, only in the pronominal paradigm one finds

\footnotetext{
${ }^{6} \mathrm{~S}$ stands for an intransitive subject, A for a transitive subject and O for transitive object, following Dixon $1994: 6$.
} 
remnants of a different marking for $\mathrm{A}$ and $\mathrm{S}$, nouns are in general in an identical case for $\mathrm{A}$ and S.

Whereas subjects/agents of converbs are restricted to arguments of the main sentence, the converb can take any direct object/patient. In contrast to the subject, the object of a converb does not need to be shared with the main verb. This is one of the features which groups converbs with other non-finite verb forms such as participles and infinitives: they are all more patient- than agent-oriented. Consider the following examples:

(26) muṃḍa pākhaṃ̣̣ika eka=rahaim dekhī +karī 'a-śakunu eu' shaven.NOM.M.SG ascetic.M.NOM.SG one=ACC see+CVB bad omen iṇi kāraṇi teha mārāwiwā kāraṇi amhe this.OBL reason.OBL he.OBL.SG kill.CAUS.INF.OBL reason.OBL we.NOM mokaliyā send.PST.M.PL 'Having seen one, a shaven ascetic, 'a bad omen' because of that (they) send us to kill him.' $14^{\text {th }}$ c. (R.G.)

(27) mrga=rahaim mati prayogi chodawī-karī āpaṇau deer=ACC intelligence.F.NOM.SG use.M.OBL.SG release-CVB own.M.SG vratu alīka-vacana-parihāra-lakṣaṇu oath.M.NOM.SG indication of the abandonment of the false speech.M.NOM.SG akhaṃḍ pratipalāai

unbroken save.PRS.3SG 
'Having released the deer by the use of intelligence (the king) is saving his own vow unbroken by the indication of the abandonment of the false speech.' $14^{\text {th }}$ c. (R.G.)

Most Indo-Aryan languages show a particular type of differential object marking, determined by the factors of animacy and definiteness: animate arguments are marked with an object case marker (either an oblique case ending or a postpositional marker), whereas inanimate arguments are only marked when they are definite. Insofar this has been investigated, the pattern of object marking in New Indo-Aryan is identical for the main verb as well as for the converbal constructions. The following examples from Hindi illustrate the differential object marking with converbs:

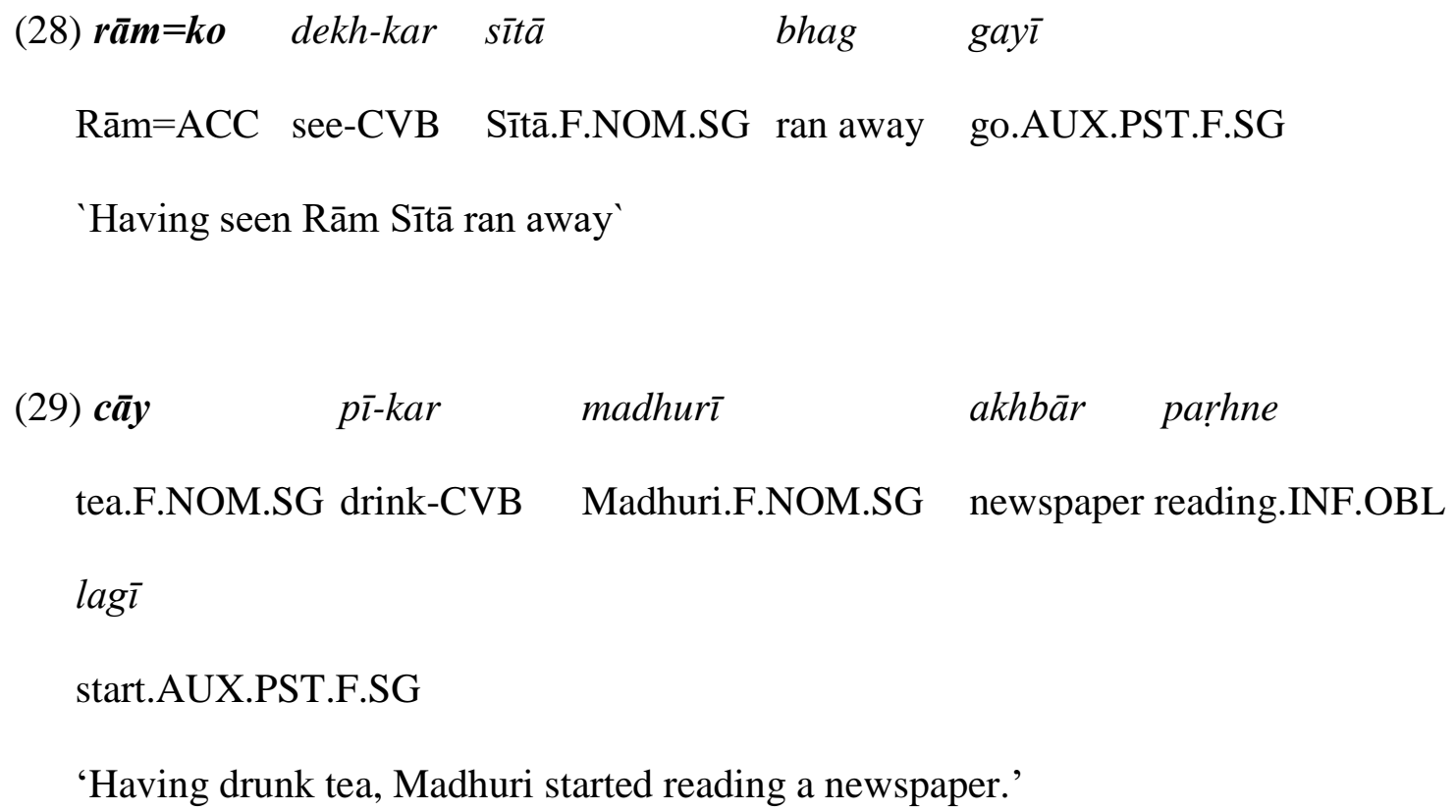

In Old Rajasthani, the pattern of the object marking follows the well-known rules of differential object marking in Indo-Aryan. In our data overtly marked O's of converbs appear in the text from the end of the $16^{\text {th }}$ century (30) and it seems that from this time onwards there is a substantial 
increase in the marking of O-arguments, which we can first observe with animate and then within animate definite arguments. From the $18^{\text {th }}$ century the marking of the latter group of arguments seems to become consistent (compare (30) with (21)).

(30) tiṇi edala=nūm $\quad$ māri-ara țiko
he.OBL.SG Adel=ACC $\quad$ kill-CVB
'He, having killed Adel, took the throne.' $16 / 17^{\text {th }}$ c. (R.G.)

In Early Western Hindi in general, the marking of $\mathrm{O}$ gradually grows in consistency. The following example illustrates that in the earliest stages, even pronominal O's are not necessarily marked (31). Even in $19^{\text {th }}$ century texts of Pahari dialects such as Kumaoni, we find unmarked pronominal O's of the converb (32). Nowadays, Pahari dialects often do not mark pronominal O's. In these dialects, finite verb constructions do not necessarily show a differential object marking pattern. This leads to the observation that unmarked O's are widely attested in contemporary Pahari dialects belonging to various branches (cf. Stroński 2011). However, more standardized languages like Kumaoni or Garhwali tend to follow the general IA differential object marking pattern, and converbs consistently take marked pronominal O's.

(31) jihi haüm gahi chanḍiyau

who.OBL.SG I.NOM catch.CVB release.PST.M.SG

'Who, having caught me, released me.' (Ch. from Miltner 1995: 50)

$$
\text { maim dekhi bari rīs ai aur }
$$
he.OBL.PL I.NOM.SG see.CVB big anger.F. come.PST.F.SG and 
maiṃ=kaṇi mari diyo

I=ACC kill give.AUX.PST.M.SG

'Having looked at me they became very angry and they killed me.' (Standard Kumauni)

(Grierson 1916: 172)

O marking in converbal constructions seems to be quite stable in Early Awadhi, already by the middle of the $16^{\text {th }}$ century (cf. both nominal and pronominal $\mathrm{O}$ in (33) and (34)).

(33) vajra-him tinakai māri urā̄i thunderbolt=ACC straw.OBL.M.SG strike.CVB make fly.PRS.3SG

'Having striken the thunderbolt with a straw he makes it fly.' (J.6.5)

(34) mohi taji samvari jo ohi marasi, kauna

I.OBL abandon.CVB remember.CVB who this.OBL die.PRS.2SG what läbha tehi hoi

profit you.OBL be.PRS.3SG

'Having abandon me, you, who remember her, die, what is then the profit for you?'

(J. 209, 10)

If we make a brief comparison with the marking of the arguments in finite constructions and its diachronic evolution, we notice that the $\mathrm{O}$ marking first occurs in the imperfective constructions. According to Khokhlova (1992: 79), O marking in perfective tenses has only been established at the turn of the $17^{\text {th }} / 18^{\text {th }}$ century, and it seems likely that this development is an analogical extension of the $\mathrm{O}$ marking in the imperfective. In our corpus, we find more than double the 
amount of marked O's in imperfective constructions than in perfectives. Research has shown that there is no noticeable difference between the introduction of $\mathrm{O}$ marking in the pronominal and nominal system, the first attestations of the pronominal $\mathrm{O}$ marking in the perfective domain are again around the 18th century (Khokhlova 1992: 79; 1995: 19-20; 2006: 167-168). If we compare this development with the O-marking in the non-finite constructions, then it seems that the O-marking with non-finites precedes the O-marking in finite constructions, and certainly the O-marking in finite perfective constructions. We might conclude that this is caused by the indifference of converbs to tense/aspect.

\section{Semantics of converbs in Old Rajasthani}

The main function of converbs in NIA seems to be clause chaining, or, according to some accounts, subordination. In NIA pure adverbial modification also occurs in converbal form,. Consider for instance the following example from Hindi, where sitting modifies the action of talking.

$$
\begin{aligned}
& \text { (35) vah baith-kar bolne laḡ } \bar{l} \\
& \text { she sit-CVB talk.INF.OBL start.PST.F.SG } \\
& \text { 'Sitting, she started talking.' }
\end{aligned}
$$

However, often this form is replaced by an adjectival participial, which refers to the subject:
(36) vah baithe
hue
bolne
$\operatorname{lag} \bar{l}$ 
she $\quad$ sit.PTCP.PST be.PTCP.PST talk.INF.OBL start.PST.F.SG

'She, sitting, started talking.,7

Although there are a number of different possible formations of converbs in Old Rajasthani, an accompanying semantic differentiation is far from being systematic. Nonetheless, some preliminary observations can be formulated.

\subsection{Converbs in light verb constructions}

Firstly, converbs are associated with the so-called light verb construction. There has been a vast literature on the category of 'light verb' in IA; however, only a few studies display a diachronic typological bias. They usually explore possible scenarios of the transition from a converb $+\mathrm{V}$ complex to a light verb, accompanied by various implications pertaining to morphosyntactic and semantic changes (cf. Hook 1991, 1993; Butt and Lahiri 2013; Slade 2013).

From the earliest Rajasthani sources a light verb construction consists of the main verb (the form in $-\bar{l}(-i))$, combined with an auxiliary. The auxiliary has lost a part of its lexical meaning and instead attributes meaning, such as reinforcement, to the meaning of the main verb. One possible account of the diachronic evolution of such constructions, which are fairly common in IndoAryan, is that the main verb was originally a converb that expressed a modification of the event.

\footnotetext{
${ }^{7}$ In recent typological literature on IA there has been attempt to explain the basic difference of the two non-finite devices in functional terms. According to Subbarao (2012: 264-272) the converb (on -kar) is subject-oriented whereas the adverbial participle does not have to be. Our data on Old Rajasthani clearly shows that adverbial participles are often part of absolute constructions which per se have different subjects, but it is a topic which requires further study.
} 
However, gradually, by frequent combining of the same lexical pairs, the conjugated verb started modifying the converb instead. At a certain moment there must have been a functional imbalance since forms in $-\bar{l}(-i)$ were used as both independent converbs and as part of light verbs. This was perhaps resolved by the introduction of more complex converbal forms. In the example (37) we can observe that there is a light verb vali gaya 'they returned' (which has as its main verb form in $-\bar{l})$ and it is preceded by the compound form pranami-kari 'having bowed' (the form is actually a juxtaposition of two converbs) and this in turn is preceded by a form in $-\bar{l}$ (here an independent converb). It is quite possible that what we observe in early Rajasthani is an attempt to employ new compound forms as linking devices and the beginning of the grammaticalization of $-\bar{l}(-i)$ forms as part of light verbs. It was however a long process and the forms in $-\bar{\imath}(-i)$ as independent converbs still occur in the $18^{\text {th }}$ century. The form in $-\bar{\imath}(-i)$ as a part of a light verb started being replaced by the root form around the $18^{\text {th }}$ century (38). At the same time, the root forms continued to serve as independent converbs (39).

\author{
(37) isaum bhaṇī praṇamī-karī vaḹ \\ such say.CVB bow.CVB-do.CVB return.CVB go.PST.M.PL \\ 'Having said this, they bowed and returned'. 14 c. (R.G.) \\ (38) so \\ bhāga gayo \\ s/he.NOM.SG flee.CVB go.PST.M.SG \\ ‘S/He ran.' 18 c. (R.G.)
}


(39) so

koṭa pāra

mahala cuṇai

chai

he.NOM wall of fort cause to fall.CVB palace build.PRS.3SG be.PRS.3SG

'After having destroyed the walls of the fort he builds a palace'. 18 c. (R.G.)

\subsection{Converbs in clause chaining}

The most common function of converbs in Indo-Aryan is quite typically, to modify in an adverbial way, the event expressed by a main verb. However, the frequent combining of converbs in one sentence which seem to indicate events which follow-up to each other, is very similar to the so-called "clause-chaining" function of converbs (Bickel 1998, Haspelmath 1995: 21). ${ }^{8}$

In our corpus, we find some examples of intricate clause-chaining, in which more than two converbs follow each other while expressing several events.
(40) sāmuhā $\bar{a} w a t \bar{a}$
muni=rahaim vāmệ̄
karī
front come.PTCP.PRS.M.PL monk=to homage.F.NOM.SG do.CVB
mārgu melhī+karī àghau cāliu
way.M.NOM.SG leave+CVB far go.PST.M.SG
'He paid homage to the monks coming from the front, he left the road and he went further on.' $14^{\text {th }}$ c. (R.C.)

\footnotetext{
${ }^{8}$ We do not enter into the discussion whether converbs are forms of subordination or so-called "cosubordination". We follow Bickel (1998: 389) and Johanson (1992) that "'converbs" are simply "subordinate" in the sense of being "dependent"' on a syntactic level. Semantically though, one can make a difference between converbs that modify the event expressed by the main verb, and converbs that are non-modifying, but pure clause-chaining. The latter type of converbs show similarities to Bisang's (1995) "narrative converbs", generating purely linear sequences.
} 
(41) namaskāra

kari, page

lāgi,

mātha-i

greeting.M.NOM.SG do.CVB foot.M.OBL.PL touch.CVB head.M-OBL.SG

hātha dirāya-nai, $\quad$ àya-nai śrī rāmacamạdraj̄

hand.M.NOM.SG give-CVB come-CVB honourable Ramacandra

ḍāwa hätha=sūm dhanuṣa uṭāya+liyo

left hand=with bow.M.NOM.SG lift.PST.M.SG+AUX.PST.M.SG

'The honourable Ramacandra greeted, touched the feet, let the hand on his head, came, and lifted the bow with his left hand.' $18^{\text {th }}$ c. (R.G.)

The last construction shows a combinations of forms on $-i$ and of the forms on $-n a i$. Based purely on the formation of the converbs in -nai, the assumption could arise that these converbs indicate a much more adverbial use, since the addition of a postposition seems to emphasize the non-verbality of the form. The following examples illustrate this, they denote a manner that specifies the action expressed by the main verb, rather than simply indicating a chain of events.

(42) tārai donūm asawāra ghorāāaurarāya-nai gayā . then both rider.M.NOM.PL horse.M.NOM.PL drive-CVB go.PST.M.SG 'Then both riders went away, driving the horses.' $18^{\text {th }}$ c. (R.G.)

However, such relatively clear occurrences of adverbial modification are few in our corpus. The dominant meaning of converbs is as clause chaining mechanisms. For instance, the following examples are almost impossible to interpret in another way than as clause chaining: 
(43) äya-nai dilī li

come-CVB Delhi.F seize.PST.F.SG

'He came and seized Delhi.' $16 / 17^{\text {th }}$ c. (R.G.)

(44) vīkānera vale rāwa kalyānamala $\bar{a} i \quad$ rāja virājaṇa

Bikaner then king.M.NOM.SG Kalyanmala come.CVB throne sit.INF $\operatorname{la} g \bar{a}$

begin.PST.M.SG

'Then, king Kalyanmal came to Bikaner and began sitting on the throne.' $16 / 17^{\text {th }}$ c. (R.G.)

Converbs ending on the suffix -ara, again, are often not used as simple adverbial modification, but rather as a subordinated clause that expresses an action going on before the main verb.

(45) akabara=rai sāthi phoja de-ara kalanora=nūm melhi-ara Akbar=with army.F.NOM.SGgive-CVB Kalanur=ACC send-CVB pātisāha hamāūm dilì āyo.

king.M.NOM.SG Humayun.NOM.SG Delhi come.PST.M.SG.

'Humayun gave the army with Akbar and sent him to Kalanur, and came to Delhi.' $16 / 17^{\text {th }}$ c. (R.G.)

Interpreting the data, we are unable to observe discrete semantic differences between the different forms of converbs. A multivariate statistical analysis performed on our data should be able to trace tendencies, which is a future undertaking. 


\section{Conclusion}

In this article, we have focused on the morphology, syntax and semantics of converbs in Old Rajasthani. We have placed them in a wider framework of Indo-Aryan, also selecting some features which are cross-linguistically attributed to the category of converbs.

There are a number of possible converb formations in Old Rajasthani; however, they are related to particular periods. The oldest forms are the most resilient, i.e. $\bar{l}$ and $i$, which seem to be nominal oblique endings transferred to the verbal root. The morphology is illustrative of the dual nature of converbs, hinging between verbality and nominality. The forms which are constructed with the multifunctional case suffix nai (identical with the dative/accusative postposition) make this even more clear. Further, we found traces of the predecessor of the Hindi converbal suffix kar, apparently deriving from the converb kari that has grammaticalized from a form on its own to a marker of other converbs, in a sort of unconventional light verb construction. The suffix -ara was also used, showing a relation between Old Rajasthani and the Pahari languages.

On the syntactic level, we focused on the same-subject constraint, and showed that this was already in place in Old Rajasthani. We found evidence of differential object marking in converbal constructions from the turn of the $16^{\text {th }}$ and $17^{\text {th }}$ centuries onwards, demonstrating that the first occurrences of a marked object of a converb must have appeared together with their occurrences in imperfective constructions. Differential object marking only appeared later with finite 
perfective constructions. This different pattern of object marking of perfective finite verbs and converbs might lead to questioning whether converbs are indeed perfective in nature, as Davison (1981) assumes. However, it is also possible that their overall stricter nominality motivates the marking of their animate object arguments.

On a semantic level, we tried to connect converbal forms with particular uses. Apart from observing that light verb constructions are limited to converbal forms on $\bar{l} / i$ and the root forms, on the basis of our qualitative interpretation of the data, we could not find any convincing evidence of typical uses of the different forms.

In the future, we plan to extend our corpus to Awadhi and Braj, and extract statistical analyses of it. The analysis of this Old Rajasthani data is however a promising start in our endeavour to describe and understand converbs on all levels in Early NIA.

\section{References}

Baruah, P.N. Dutta. 1980. An intensive course in Assamese. Mysore: CIIL.

Bickel, Balthasar \& Yogendra P. Yadav. 2000. A fresh look at grammatical relations in IndoAryan. Lingua 110: 343-373.

Bickel, Balthasar. 1998. Review article of 'Converbs in cross-linguistic perspective'. Linguistic typology 2: 381-397. 
Bisang, Walter. 1995. Verb serialization and converbs - differences and similarities. In Martin Haspelmath \& Ekkehard König (eds.). Converbs in Cross-linguistic perspective. Berlin: Mouton de Gruyter. 137-188.

Bloch, Jules. 1965. Indo-Aryan. From the Vedas to modern times. Paris: Librairie D'amerique Et D'orient Adrien - Maisonneuve.

Chālise, Bidurkumar. 2006. Aitihāsika abhilekhakā ādhāramā nepālī bhāṣākā vyākaraṇa tatvamā kramika vikāsako adhyayana. [A study on the stadial development in the grammar of the Nepali language based on the historical inscriptions]. Unpublished $\mathrm{PhD}$ thesis. Kathmandu: Tribhuvan University.

Davison, Alice. 1981. Syntactic and semantic indeterminacy resolved: A mostly pragmatic analysis for the Hindi conjunctive participle. In Peter Cole (ed.), Radical pragmatics. New York: Academic Press, 101-128.

Haspelmath, Martin. 1995. The converb as a cross-linguistically valid category. In Martin Haspelmath \& Ekkehard König (eds.). Converbs in cross-linguistic perspective. Berlin: Mouton de Gruyter. 1-56.

Hutt, Michael. 1997. Modern literary Nepali. An introductory reader. New Delhi: Oxford University Press.

Jaworski, Rafał. 2015. IATagger. http://rjawor.vm.wmi.amu.edu.pl/tagging/

Johanson, Lars. 1992. Periodische Kettensätze im Türkischen. Wiener Zeitschrift für die Kunde des Morgenlandes. 82: 201-211. 
Kachru, Yamuna. 1981. On the syntax, semantics and pragmatics of the conjunctive participle in Hindi-Urdu. Studies in the linguistic sciences 11(2): 35-49.

Khokhlova, Ludmila V. 1992. Trends in the development of ergativity in New Indo-Aryan. Osmania Papers in Linguistics 18, 71-89.

Khokhlova, Ludmila V. 1995. The Development of patient-oriented constructions in late Western NIA Languages. Osmania Papers in Linguistics 21, 15-51.

Khokhlova, Ludmila V., 2006. Sintaktičeskaja evolucija zapadnych novoindijskich jazykov v 1520 vv. [Syntactic evolution of Western New Indo-Aryan languages in 15-20 c.]. In: Dybo (et al. eds.) Aspekty komparativistiki [Aspects of comparative studies]. Moskva: Rosijskij Gosudarstvennyj Gumanitarnyj Universitet (Orientalia et Classica: Trudy Instituta Vostočnych Kultur i Antičnosti: Vypusk VIII). 151-186.

Masica, Colin. 1976. Defining a linguistic area. South Asia. Chicago: University of Chicago Press.

Miltner, Vladimir. 1995. Old Hindi Reader. Prague: Karolinum - Charles University Press.

Pokharel, Bālkṛṣna. 1964. Pānca śaya varșa [Five hundred years]. Lalitpur: Jagadambāprakāśan.

Reinöhl, Uta. 2016. A single origin of Indo-European primary adpositions? Unveiling the IndoAryan branch-off. Diachronica 33(1): 95-130.

Saksena, Baburam.1971 [1937]. Evolution of Awadhi. Delhi: Motilal Banarsidass.

Stroński, Krzysztof. 2009. On the origin of the ergative postposition in Hindi. Rocznik Orientalistyczny LXII/1: 175-186. 
Stroński, Krzysztof. 2011. Synchronic and diachronic aspect of erativity in Indo-Aryan.Poznań: Wydawnictwo Naukowe UAM.

Stroński, Krzysztof \& Tokaj, Joanna. 2015. The diachrony of cosubordination - lessons from Indo-Aryan. Paper presented at the 31st South Asian Languages Analysis Roundtable (SALA31), Lancaster 14-16 May 2015. Extended abstract available at: http://ucrel.lancs.ac.uk/sala31/doc/ABSTRACTBOOK maincontent.pdf.

Subbarao, Kurumuri V. 2012. South Asian languages: a syntactic typology. Cambridge: Cambridge University Press.

Śukla, Prabhākar. 1965. Jāyas̄̄ kī bhāṣā [The language of Jayasi]. Lakhnaū: Lakhnaū Viśvavidyālay.

Tessitori, Luigi P. 1914-16. Notes on the Grammar of the Old Western Rajasthani with Special Reference to Apabhramsa and to Gujarati and Marwari. Indian Antiquary 43:5.

Tikkanen, Bertil. 1995. Burushaski converbs in their South and Central Asian areal context. In Martin Haspelmath \& Ekkehard König (eds.). Converrbs in cross-linguistic perspective. Berlin: Mouton de Gruyter. 487-528.

Verbeke, Saartje. 2013. Alignment and ergativity in the New Indo-Aryan languages. Berlin: Mouton de Gruyter.

Wallace, William. 1982. The evolution of ergative syntax in Nepali. Studies in the linguistic sciences 12(2): 147-211. 


\section{Primary sources:}

Bhānāvat, Narendra and Kamal, Lakshmi (eds.). 1997-1998. Rājasthānī gadya: vikās aur prakāś

[Rajasthani prose: development and publicity], Āgrā: Śrīrām Mehrā end Kampan̄̄. (R.G.)

Gautam Manmohan, 1954. Jāyasī granthavalī. Dehli: Rigal Buk Dipo. (J.) 